\title{
High-Achievers Scholarship Program in Computer Science and Mathematics
}

\section{Dr. Rahman Tashakkori, Appalachian State University}

Rahman Tashakkori received his PhD in Computer Science from Louisiana State University in 2001. He is currently serving as the Chair and Lowe's Distinguished Professor of Computer Science at Appalachian State University. He has led several NSF projects that include CSEMS, S-STEM, STEP, and RET.

\section{Dr. Cindy Norris, Appalachian State University}

Dr. Cindy Norris is a Professor in the Department of Computer Science at Appalachian State University. She received her PhD in Computer Science from the University of Delaware. Dr. Norris teaches courses in Computer Systems and is interested in Computer Science education research, in particular tools that enable students to better understand concepts in Computer Systems.

\section{Dr. Mary E. Searcy, Appalachian State University \\ Dr. Vicky Klima \\ Dr. James T. Wilkes, Appalachian State University}

James is a beekeeper, college professor, farmer, and entrepreneur. He is a Professor in the Department of Computer Science at Appalachian State University in Boone, NC and works at the intersection of computing and honey bees on various projects including the Bee Informed Partnership. He also operates a diverse family farm that includes a thriving honey bee business. Lastly, James is co-founder of Blowing Rock Software, the parent company of Hive Tracks. 


\title{
High-Achievers Scholarship Program in Computer Science and Mathematics
}

Rahman Tashakkori, Cindy A Norris, Mary E Searcy, Vicky W Klima, and James T Wilkes

\author{
Appalachian State University
}

Appalachian State University (ASU) has received four CSEMS/S-STEM awards since 2001 with the most recent award in 2013. These projects have provided scholarships to 165 economically disadvantaged, often first generation, college students. Overall, the retention rate of our scholars has been $87 \% ; 12 \%$ of our scholars have completed an undergraduate degree and continued on to a graduate program. The retention rate has increased as our program has improved over years. The retention rate of the current cohort is $92.3 \% ; 31 \%$ of whom completed an undergraduate degree and went on to a graduate program. Our retention numbers are significantly higher than the $31 \%$ national average reported by U.S. Department of Education.

\section{Introduction}

The goals of the program are to increase the high technology workforce and the number of CS and Math students pursuing graduate degrees by providing opportunities for talented, economically disadvantaged students. Out of the 39 participants ( 9 Math, $30 \mathrm{CS}$ ) in the current S-STEM program, 38 demonstrated high financial need and one had moderate need. Our program has retained all but three of the scholars $(92.3 \%)$. One of the three students who resigned from the program joined the military after his first semester and two students switched from CS to Computer Information Systems. Our S-STEM program also encourages students to continue their education and 13 of the 39 students have pursued graduate studies at our university. Considering that $96 \%$ of our university's population is Caucasian, we have had some success in diversifying our S-STEM program where $15 \%$ are non-white. In addition, $23 \%$ of our S-STEM population is female and more than $68 \%$ of our S-STEM scholars are first generation college students. At present, the significant components of the program include: leadership building, collaboration, research, and academic support. Participants rank research as the component that is the most important to them and their career goals.

\section{Program Activities}

The activities of our S-STEM program, entitled the High Achievers Scholarship Program in Computer Science and Mathematics, center around a weekly STEM seminar. Scholars are required to attend this one credit hour, graded seminar. Undergraduate students can earn a maximum of three hours for attending the seminar; none of the hours count toward a graduate degree. During the seminar, students have the opportunity to listen to guest speakers, engage in leadership building activities, and present their own research. Outside of the STEM seminar, scholars are required to collaborate on a research project and attend study halls. Other activities are also promoted to encourage the development of an S-STEM community, including intramural sports, movie nights, hiking, etc. A small number of students from two other privately funded scholarship programs, ECRS and McKinney, participate in the S-STEM program activities, including the STEM seminar; the retention rate of these students, although also high, is not included in this paper.

In an S-STEM program survey during the 2016-2017 academic year, the 21 scholars in the program at that time were asked to rank the S-STEM program components, with 1 given the 
highest ranking. Table 1 contains the ranking. The score column provides the ranking as a weighted average. As can be seen, scholars rank Research Experiences as the most important component to them and their career goals.

Table 1 - Scholars' Ranking of Program Components

\begin{tabular}{|c|c|c|c|c|c|}
\hline & $\mathbf{1}$ & $\mathbf{2}$ & $\mathbf{3}$ & $\mathbf{4}$ & Score \\
\hline Research Experience & $38.10 \%$ & $38.10 \%$ & $4.76 \%$ & $19.05 \%$ & 2.05 \\
\hline Collaborative Experience & $23.81 \%$ & $38.10 \%$ & $38.10 \%$ & $0 \%$ & 2.14 \\
\hline Leadership Building Experiences & $19.05 \%$ & $14.29 \%$ & $23.81 \%$ & $42.86 \%$ & 2.91 \\
\hline Academic Support Experiences & $19.05 \%$ & $9.52 \%$ & $33.33 \%$ & $38.10 \%$ & 2.90 \\
\hline
\end{tabular}

\subsection{Research}

Our S-STEM scholars are organized into research clusters to work together in teams of three or four to solve CS, Math, or interdisciplinary problems. We believe that the opportunity to participate in research significantly contributes to the retention of these students. Our students indicate research as the most important component of the program and about $85 \%$ of the surveyed scholars indicated they applied to the program because of its research emphasis.

In addition to working in STEM seminar research clusters, many of the of S-STEM scholars work on a research project under the direction of a faculty mentor. During the 2016-2017 academic year, about 95 percent of the scholars did so. About 70 percent of the scholars presented their work at our university's Undergraduate Research Day and 23 percent of the scholars presented their work at a regional or national conference.

\subsection{Collaboration}

Our scholars rank collaboration as the second most significant component to them and their careers. In addition, 100\% agreed or strongly agreed that the S-STEM program activities prepared them to work in collaborative environments. The collaborative environments also enabled scholars to develop a strong sense of community, which contributed to the high rate of retention.

\subsection{Academic Support}

One of the goals of the project is to improve the student support infrastructure available to all CS and Math students. The program offers study halls, mentoring, and tutoring services to all Computer Science and Mathematics students. Scholars are required to attend study halls for 2 hours each week. In addition, the 2016-2017 survey indicated that 85 percent of the scholars participate in group study sessions, 71 percent were mentored by another scholar, and 62 percent were mentors of other scholars.

\subsection{Leadership Building}

Several times during the past two years, ASU professor, Dr. Jim Street, of the Office of Student Leadership Development conducted leadership workshops. These workshops provided students the opportunity to learn about themselves, learn how to collaborate with others and work in teams, and develop their capacity to lead. These skills are important preparation for the workforce. 


\section{Program Improvements}

The retention rate of our programs has increased as we have improved the program. In particular, we have increased our scholars' sense of connection to the program and increased the value of the program to them. We have accomplished this via the following: connecting with the realworld experts, instilling a sense of ownership, creating a culture of engagement, and increasing the quality of research and innovation. In our initial program, some students resisted the requirements of the program; they wanted the scholarship money but did not want to participate in the activities that we considered critical for their success. Our current scholars are able to see the significant academic and professional successes of our past scholars and are much more inclined to embrace the activities of the program because they attribute these successes to our program.

\section{Retention}

A recent survey of both current and former scholars specifically asked participants to "Indicate the one or two most significant components of the scholarship program that you believe contributed to you remaining a STEM student." 36 scholars (15 current, 21 former) completed the survey. An analysis of the results found that almost all responses referred to either the opportunity to perform research, community and friendship, and/or the financial support. Although current scholars largely named research as the component that is most significant to them, when asked which component contributes to them staying in the STEM major, the current and former scholars indicate community and friendship. Specifically, 50 percent of all survey participants named research and 63.8 percent indicated community (note: survey participants can indicate both). In addition, the perception that community was the most influential factor upon their retention is much stronger among alumni scholars.

\section{Conclusions and Acknowledgements}

A U.S. Department of Education study found that the STEM attrition rate for computer/information sciences major was 59\%, the highest among the STEM disciplines [1]. Our current S-STEM program has an attrition rate of just $7.7 \%$. We attribute the success of our program to activities that establish a strong sense of community among participants and allow students to work on a research project. We thank the National Science Foundation for the support of our programs.

\section{REFERENCES}

[1] X. Chen. 2013. STEM Attrition: College Students' Paths Into and Out of and Out of STEM Fields (NCES 2014-001). (2013). 